\title{
Philosophy, Science, Ideology and the establishment of science as a profession
}

David Banks

\section{(2) OpenEdition}

1 Journals

Electronic version

URL: http://journals.openedition.org/asp/1084

DOI: $10.4000 /$ asp. 1084

ISBN: 978-2-8218-0396-1

ISSN: 2108-6354

Publisher

Groupe d'étude et de recherche en anglais de spécialité

Printed version

Date of publication: 1 March 2004

Number of pages: $69-80$

ISSN: 1246-8185

\section{Electronic reference}

David Banks, «Philosophy, Science, Ideology and the establishment of science as a profession », ASp [Online], 43-44 | 2004, Online since 30 March 2010, connection on 03 May 2019. URL : http:// journals.openedition.org/asp/1084; DOI : 10.4000/asp.1084

This text was automatically generated on 3 May 2019.

Tous droits réservés 


\title{
Philosophy, Science, Ideology and the establishment of science as a profession
}

\author{
David Banks
}

1 What is true of linguistics in general is true also of that sub-branch of linguistics which we call ESP. Just as diachronic linguistics can be of help in understanding problems in synchronic linguistics, so understanding how a particular specialized genre has developed can help in the understanding of how that genre functions today. It is therefore of interest to consider how scientific English came into being in the late seventeenth century, and this study ${ }^{1}$ fits into that domain. In this article I hope to show that the establishment of science as a profession began towards the end of the seventeenth century, when Isaac Newton was rising to dominance in the scientific world of that period. I shall first look at the OED entries for a number of lexical items related to professions to see which of them would have been appropriate for Newton and his contemporaries. I will then consider in detail two works from the period: Isaac Newton's Opticks, and Christiaan Huygens' Traité de la lumière. I will attempt to show that certain linguistic features of these works depend on the ideologies which lie behind these two writers' differing conceptions of scientific activity, and that this has a bearing on the establishment of science as a profession. There have been very few contrastive linguistic studies comparing French and English scientific texts of this period. Gross et al. (2002) is a rare example. They consider 100 ten-line passages from the Philosophical Transactions, 71 from Mémoires de l'Académie Royale des Sciences, and 27 from Journal des Sçavans. They discuss style and presentation, relating this to grammatical features. However, when they quote from the French texts, they do so in English translation. The terminology used in this article is that of Systemic Functional Linguistics (Halliday 1994). 


\section{Some lexicological background}

2 According to the $O E D$, the adjective professional began life in the early 15th century with a meaning that is now rare or obsolete, that of "pertaining to or marking entrance to a religious order". By 1747 (date of the earliest citation) it was "pertaining to, proper to or connected with [...] one's profession or calling", and by 1793, "engaged in one of the learned or skilled professions, or in a calling considered socially superior [...]". And before the end of the 18th century (1798), it had attained its contemporary meaning: "that follows an occupation as his [...] profession [...] or means of livelihood [...] applied to one who follows [...] an occupation generally engaged in as a pastime; hence used in contrast with amateur [...]". The noun professional does not appear until a comparatively late date. The first OED citation is in 1811 with the meaning of "one who makes a profession or business of any occupation, art or sport otherwise usually or often engaged in by amateurs [...]", and in 1848 it appears as "one who belongs to one of the learned or skilled professions". Hence, the word professional, either as adjective or noun, was not one that was available, in its modern sense, to Newton and his contemporaries.

The word profession had been around longer than professional. Like professional, it started life with a religious connotation; a citation from 1225 is given as "the declaration, promise or vow made by one entering a religious order". Three centuries later (1526) it has become "the action of declaring, acknowledging, or avowing an opinion, belief, intention, practice, etc.". By 1541 this has become more precise: "the occupation which one professes to be skilled in and to follow. A vocation in which a professed knowledge of some department of learning or science is used [...]. Applied [...] to the three learned professions of divinity, law and medicine". And by 1576 this has been widened to "any calling or occupation by which a person habitually earns his living". The OED goes on to tell us that today this is "usually applied to an occupation considered to be socially superior to a trade or handicraft, but formerly [...] including these". The word profession then would not have been appropriate for Newton. What he and those like him did, did not fall into the domain of divinity, law or medicine. In Newton's personal case, it is probably worth remembering, in relation to divinity, that he went to great lengths to obtain a royal dispensation from the requirement that university dons should take holy orders. This was directly related to the fact that he was a closet Arian. Since this meant he did not believe in the Trinity, he would have found it impossible to take the vows necessary to take holy orders in the Anglican Church. He would almost certainly have been hounded out as a heretic had this become public knowledge (White 1997, Fara 2002, Gleik 2003).

4 Newton was of course a professor. As early as 1380, the OED has a citation for the meaning "A public teacher or instructor of the highest rank in a specific faculty or branch of learning [...] who holds an endowed or established chair in a university or one of its colleges". Newton became Lucasian Professor of Mathematics at Cambridge in 1669 at the amazingly young age of 26 . He did not resign from his chair until 1701, although he had left Cambridge for London in 1696 (White 1997).

We would now refer to Newton's activity as science, but in the 14th century this word meant "The state or fact of knowing; or cognizance of something specified or implied" (1340); during that century it was also applied to "knowledge acquired by study; acquaintance with or mastery of any department of learning", or "a particular branch of 
knowledge or study; a recognized department of learning". In the Middle Ages the branches of study which were generally recognized were known as the seven liberal arts, and they were grammar, logic, rhetoric, arithmetic, music, geometry and astronomy. It is only in 1725 that we find it being used "in a more restricted sense: a branch of study which is concerned either with a connected body of demonstrated truths or with observed facts systematically classified [...] by being brought under general laws [...]". It is only towards the end of the 19th century (1867) that the contemporary sense of the word appears: "In modern use, often treated as synonymous with "Natural and Physical Science', and thus restricted to those branches of study that relate to the phenomena of the material universe and their laws [...]". The OED points out that in the 17th and 18th centuries, what we now call "science" was then called "philosophy".

The word scientist is of comparatively recent coinage. The first OED citation is from 1834, with the meaning: "a person with expert knowledge of a science; a person using scientific methods". The 1834 quotation is in itself instructive:

We are informed that this difficulty [that they had no collective name] was felt very oppressively by the members of the British Association for the Advancement of Science [...]. Philosophers was felt to be too wide and too lofty a term [...]. Savans was rather assuming [...] some ingenious gentleman proposed that by analogy with artist they might form scientist but this was not generally palatable.

7 Despite the feelings of the members of the British Association for the Advancement of Science, this was, as we now know, the word which stuck.

8 And so to philosophy, whose general meaning is given with a 1340 citation as "the love, study, or pursuit of wisdom, or of knowledge of things and their causes, whether theoretical or practical", and a little later (1387) as "that more advanced knowledge or study, to which, in the medieval universities the seven liberal arts were recognized as introductory; it included the three branches of natural, moral, and metaphysical philosophy". However the meaning which equates "philosophy" with "natural philosophy" has a quotation as early as 1297 , with the meaning: "the knowledge or study of nature, or of natural objects and phenomena [...] now usually called science". The quotations for this meaning continue until the beginning of the 19th century, but it is said to be now rare or obsolete.

The word philosopher has hardly changed since the early 14th century when it occurs with the meaning: "a lover of wisdom; one who devotes himself to the search of fundamental truth; one versed in philosophy or engaged in its study", but the text goes on to say that it was used "formerly in a wide sense, including men learned in physical science (physicists, scientists, naturalists) [...]". Newton is included in that former wide sense. He would have thought of himself as a philosopher.

\section{The corpus}

10 Newton's work on mathematics and astronomy fits into the traditional seven liberal arts, but not his work on optics. While Newton had published his mathematical and astronomical work in Latin, for his work on optics he turned to English. Huygens initially welcomed Newton's work, but later rejected it, and he too worked on optics and published it in Traité de la lumière. Newton's Opticks, described by Gross as "a rhetorical masterpiece" (1996: 122), was written in the period 1675-1687, but he delayed publication until 1703. This was probably due to the reception which his first paper on optics 
received. This paper, "New Theory about Light and Colors", written in the then common epistolary form, was published in the Philosophical Transactions of the Royal Society in 1672. Newton seems to have thought that this paper would be immediately and universally accepted, and was thus surprised at the mixed reception it attracted. He was already something of a recluse, and the result was that he withdrew until 1703, that is, until after the death of Hooke, President of the Royal Society and one of his main critics. It was then that he published Opticks, and within a few months he was himself elected to take Hooke's place as President of the Royal Society (Bazerman 1988, Vickers 1987, White 1997, Atkinson 1999, Gleik 2003). Opticks had run to a 4th edition by 1730 , and this is the edition usually used today. Huygens published Traité de la lumière in 1690. This provides an interesting comparison between two books, dealing with the same scientific topic, written at more or less the same period, one of which is in English, the other in French.

11 Although Newton and Huygens were both "philosophers", in the terminology of their day, they were not practicing the same type of philosophy. That which was practiced by Newton was known as the experimental philosophy, while that of Huygens was the mechanical philosophy (Jones 1982). The experimental philosophy derives from Bacon, and is based on the principle that experimental data must be sought first, and on their basis a theory can be constructed. The mechanical philosophy follows the Cartesian precept that reason is primary, and that experimental data can be subsequently sought to verify the theory that reason has postulated. The positions of these two authors are clear from the beginnings of the two works concerned. Newton's first paragraph begins:

My Design in this Book is not to explain the Properties of Light by Hypotheses, but to propose and prove them by Reason and Experiments: In order to which I shall premise the following Definitions and Axioms. (Newton 1979 [1730]: 2)

"Hypothesis" has a peculiarly Cartesian ring. The hypothesis was the very basis of the Cartesian method, so in eschewing the notion of hypothesis from the very beginning, Newton is obviously and deliberately setting himself up in opposition to the Cartesians. This peremptory way of setting Cartesianism aside has an almost pugnacious feel about it. Huygens' third paragraph contains the following:

J'essaierai donc dans ce livre, par des principes reçus dans la Philosophie d'aujourd'hui, de donner des raisons plus claires et plus vraisemblables, premièrement de ces propriétés de la lumière directement étendue ; secondement de celle qui se réfléchit par la rencontre d'autres corps. Puis j'expliquerai les symptômes des rayons qui sont dits souffrir réfraction en passant par les corps diaphanes de différente espèce. (Huygens 1992 [1690]: 52)

Here, Philosophie d'aujourd'hui can only refer to Cartesianism, and indeed Descartes is referred to in the following paragraph and frequently throughout the book. Thus Newton's and Huygens' opposing viewpoints on scientific method are clear from the very start.

The corpus consists of three extracts from each of the books. The first extract is the beginning of the book, and includes the above quotations. The second is from what I would term an experimental section, although as will be seen, this means something rather different for each of our two authors. The third section is more of a discussion section, but deals with the same subject in each case: the section in Opticks is headed Observations concerning the Reflexions, Refractions and Colours of thin transparent Bodies, while that in Traité de la lumière has the heading Des figures des corps diaphanes Qui servent à la Réfraction, et à la Réflexion. The three extracts from Newton will be labelled N1, N2, N3, and those from Huygens, $\mathrm{H} 1, \mathrm{H} 2, \mathrm{H} 3$. The number of words in the corpus is as follows: 


\begin{tabular}{|l|l|l|l|}
\hline N1 & N2 & N3 & N total \\
\hline 1459 & 1789 & 1493 & 4741 \\
\hline H1 & H2 & H3 & H total \\
\hline 1806 & 1977 & 2048 & 5831 \\
\hline & & Grand total & 10,572 \\
\hline
\end{tabular}

15 In what follows, I shall consider two linguistic features: personal pronouns functioning as subject, and nominalized processes. A wider range of linguistic features is considered in Banks (forthcoming).

\section{Personal pronoun subjects}

In Newton's text the pronouns which occur as subject are I and you. In Huygens' text, je, nous and on are all used as subject pronouns. Table 1 gives the numbers and frequencies of these pronouns functioning as subject. The figures for Newton include 8 cases of ellipted $I$

Table 1. Personal pronouns functioning as subject

\begin{tabular}{|c|c|c|c|c|c|c|}
\hline \multicolumn{2}{|l|}{ Newton } & \multicolumn{2}{|l|}{ I } & \multicolumn{2}{|l|}{ you } & total \\
\hline \multicolumn{2}{|l|}{ number } & \multicolumn{2}{|l|}{59} & \multicolumn{2}{|l|}{5} & 64 \\
\hline \multicolumn{2}{|l|}{ per 1000 words } & \multicolumn{2}{|c|}{12.4} & \multicolumn{2}{|l|}{1.1} & 13.5 \\
\hline \multicolumn{2}{|l|}{ per 100 finite verbs } & \multicolumn{2}{|c|}{17.3} & \multicolumn{2}{|l|}{1.5} & 18.8 \\
\hline Huygens & je & & nous & & on & total \\
\hline number & 27 & & 17 & & 45 & 89 \\
\hline per 1000 words & 4.6 & & 2.9 & & 7.7 & 15.3 \\
\hline per 100 finite verbs & 4.9 & & 3.1 & & 8.2 & 16.2 \\
\hline
\end{tabular}

17 It will be noted while overall figures are similar for the two authors, in terms of frequency, Huygens uses more personal pronoun subjects judged according to the number of words, but Newton uses more measured according to the number of finite verbs. This is due to the rather longer and more complex sentence structure used by Huygens. The pronouns which occur in Newton are dominated by I, the occurrence of you being marginal, $8 \%$ of Newton's personal pronoun subjects. In Huygens all three pronouns, je, nous and on, occur in non-negligible proportions, 30\%, 19\%, and $51 \%$ respectively. It could be argued that Newton's text is more personalized, having a greater 
emphasis on the I pronoun which thus plays a more central role than je does in Huygens' text.

Despite the overall numbers of pronouns, differences emerge when their distribution by process type, that is, the process type of the verb of which they are subject, is considered. In the following tables, you has been eliminated because of the small number involved, and the figures for I do not include ellipted examples.

Table 2. Personal pronoun subjects by process type

Newton - I

\begin{tabular}{|l|l|l|l|l|}
\hline & Material & Mental & Relational & Verbal \\
\hline N1 & - & 8 & - & 8 \\
\hline N2 & 13 & 5 & 2 & - \\
\hline N3 & 2 & 10 & - & 3 \\
\hline N Tot. & 15 & 23 & 2 & 11 \\
\hline & $29 \%$ & $45 \%$ & $4 \%$ & $22 \%$ \\
\hline
\end{tabular}

Huygens $-j e$

\begin{tabular}{|l|l|l|l|l|}
\hline & Material & Mental & Relational. & Verbal \\
\hline H1 & - & 6 & 2 & 8 \\
\hline H2 & 1 & 2 & - & 4 \\
\hline H3 & - & 1 & - & 3 \\
\hline H Tot. & 1 & 9 & 2 & 15 \\
\hline & $4 \%$ & $33 \%$ & $7 \%$ & $56 \%$ \\
\hline
\end{tabular}

Huygens - nous

\begin{tabular}{|l|l|l|l|l|}
\hline & Material & Mental & Relational & Verbal \\
\hline H1 & - & 3 & 1 & - \\
\hline H2 & - & 2 & - & 3 \\
\hline H3 & - & 2 & - & 4 \\
\hline
\end{tabular}




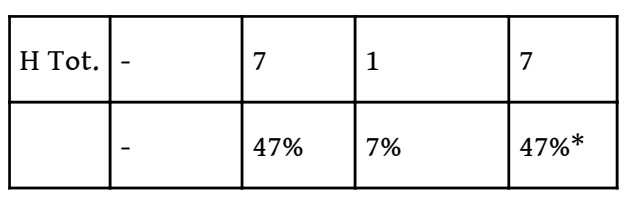

* Discrepancies due to rending

Huygens - on

\begin{tabular}{|l|l|l|l|l|}
\hline & Material & Mental & Relational & Verbal \\
\hline H1 & - & 9 & 3 & - \\
\hline H2 & 3 & 5 & 9 & 1 \\
\hline H3 & - & 10 & 2 & 3 \\
\hline H Tot. & 3 & 24 & 14 & 4 \\
\hline & $7 \%$ & $53 \%$ & $31 \%$ & $9 \%$ \\
\hline
\end{tabular}

Mental process is the most common process type which occurs with all of these pronouns; it accounts for $45 \%$ of Newton's I, and 33\%, $47 \%$ and $53 \%$ of Huygens' je, nous and on respectively. From this point of view the two authors might be thought of as similar; however, the second most common process type for Newton's $I$ is material process, accounting for $29 \%$, whereas, material process is rare for all three of Huygens' pronoun subjects. This reflects the fact that in Newton's text the argument is based on experiment, that is, on someone doing things; in Huygens' text no-one does anything. Facts are known and reasoning takes place on the basis of these facts. The comparative absence of material process in the case of Huygens is to some extent compensated by the presence of verbal process with je (56\%), and nous (47\%), and relational process with on (31\%). In the case of Newton's I, verbal process occurs to some degree (22\%), but rather less than with je and nous, and relational process is rare.

The fact that these figures reflect the experimental and Cartesian standpoints of these two authors can be illustrated with the following extracts:

In a very dark Chamber, at a round Hole, about one third part of an Inch broad, made in the Shut of a Window, I placed a Glass Prism, whereby the Beam of the Sun's Light, which came in at that Hole, might be refracted upwards toward the opposite Wall of the Chamber, and there form a colour'd Image of the Sun. The Axis of the Prism (that is, the Line passing through the middle of the Prism from one end of it to the other end parallel to the edge of the Refracting Angle) was in this and the following Experiments perpendicular to the incident Rays. About this axis I turned the Prism slowly, and saw the refracted Light on the Wall, or coloured Image of the Sun, first to descend, and then to ascend. Between the Descent and Ascent, when the Image seemed Stationary, I stopp'd the Prism, and fix'd it in that Posture, that it should be moved no more. (Newton 1979 [1730]: 27-28)

Here we find a description of an experiment. Newton is carrying out this experiment himself, and so he is doing things: "I placed a Glass Prism [...] I turned the Prism slowly [... ] I stopp'd the Prism, and fix'd it". Moreover, Newton's action is purposeful action: 
"whereby the Beam [...] might be refracted upwards [...] and there form a color'd image". And Newton is the observer of this, as when he "saw the refracted light". Compare this with a passage from Huygens:

Premièrement donc quand la matière éthérée ne pénétrerait aucunement les corps transparents, leurs particules mêmes se pourraient communiquer successivement le mouvement des ondes, de même que celles de l'Ether ; étant supposées, comme celles-ci, de nature à faire ressort. Et cela est aisé à concevoir pour ce qui est de l'eau, et des autres liqueurs transparentes, comme étant composées de particules détachées. Mais il peut sembler plus difficile à l'égard du verre, et des autres corps transparentes et durs; parce que leur solidité ne semble pas permettre qu'ils puissent recevoir du mouvement que dans toute leur masse à la fois. Ce qui pourtant n'est pas nécessaire, parce que cette solidité n'est pas telle qu'elle nous parait ; étant probable que ces corps sont plutôt composés de particules, qui ne sont que posées les unes auprès des autres, et retenues ensemble par quelque pression de dehors d'une autre matière, et par l'irrégularité des figures. (Huygens 1992 [1690]: 75-76)

In this corresponding passage from Huygens, he talks a great deal about the physical phenomena: "la matière éthérée ne pénétrerait aucunement les corps transparents [...] étant composées de particules détachées [...] leur solidité ne semble pas permettre [...] ces corps sont plutôt composés de particules", but neither Huygens, nor any other experimenter, intervene in these processes. Huygens is basing his argument on what he takes to be fact, but not on an experimental process.

\section{Nominalized processes}

Nominalized processes are a form of grammatical metaphor (Halliday 1994). The normal or congruent way of encoding a process is by means of a verb. If some other method is used, such as a noun, then this constitutes an example of grammatical metaphor. This is syntactically significant since the nominalized form has all the syntactic characteristics of a noun: it can be modified and qualified, it can function as subject, complement, prepositional completive, etc. It also takes on some of the semantic characteristics of the noun, that is, it is to some extent reified or objectified, thus giving it more permanence than the corresponding verbal form. Partly for these reasons, it has taken on particular significance in scientific writing (Halliday 1988, 1998, Halliday \& Martin 1993, ${ }^{2}$ Banks 1999, 2001, 2003).

In overall terms, Newton's and Huygens' use of nominalized processes is similar. This can be seen in Table 3.

Table 3. Nominalized Processes

Newton

\begin{tabular}{|l|l|l|l|l|l|}
\hline & Material & Mental & Relational & Verbal & Total \\
\hline Tokens & 121 & 9 & 8 & 3 & 141 \\
\hline Types & 24 & 7 & 6 & 3 & 40 \\
\hline$\%$ tokens & 85.8 & 6.4 & 5.7 & 2.1 & \\
\hline
\end{tabular}




\begin{tabular}{|l|l|l|l|l|l|}
\hline \% types & 60.0 & 17.9 & 15.4 & 7.7 & \\
\hline Token/Type & 5.0 & 1.3 & 1.3 & 1.0 & 3.5 \\
\hline Tokens/1000 words & 25.5 & 1.9 & 1.7 & 0.6 & 29.7 \\
\hline
\end{tabular}

Huygens

\begin{tabular}{|l|l|l|l|l|l|}
\hline & Material & Mental & Relational & Verbal & Total \\
\hline Tokens & 116 & 36 & 8 & 1 & 161 \\
\hline Types & 31 & 18 & 8 & 1 & 58 \\
\hline \% tokens & 73.4 & 20.9 & 5.1 & 0.6 & \\
\hline \% types & 53.4 & 31.0 & 13.8 & 1.7 & \\
\hline Token/Type & 3.7 & 1.8 & 1.0 & 1.0 & 2.7 \\
\hline Tokens/1000 words & 19.9 & 6.2 & 1.4 & 0.2 & $27.6 *$ \\
\hline
\end{tabular}

* DISCREPANCIES DUE TO ROUNDINg

As can be seen, Newton uses 29.7 nominalized processes per 1000 words, while Huygens uses 27.2. Newton also tends to reuse his nominalizations more than Huygens does. On average, Newton uses each of his nominalization types 3.5 times, whereas Huygens uses his 2.7 times. Since nominalized processes frequently constitute technical terms, this might be seen as an indication that Newton is building up a technical vocabulary to a greater degree than Huygens. When these figures for nominalization are distributed by process type further differences begin to emerge. The figures for relational and verbal process are small, even marginal, and of the same order for both authors. The majority of nominalized processes are material: for Newton this is $86 \%$, for Huygens, although still the majority, it is rather less, 73\%. More significantly Huygens uses a comparatively large proportion (21\%) of nominalized mental processes, while only $6 \%$ of Newton's nominalized processes are mental. This indicates that whereas in Newton's case nominalization is very largely a question of material processes, other processes only being nominalized to a marginal extent, in Huygens' case, although material processes are nominalized to an extensive degree, mental processes are also nominalized to a significant extent. Thus in Huygens, the reasoning process itself is nominalized, a feature which is rare in Newton's text, which virtually restricts nominalization to physical phenomena.

This is illustrated by the following extracts:

Refrangibility of the Rays of Light, is their Disposition to be refracted or turned out of their Way in passing out of one transparent Body or Medium into another. And a greater or less Refrangibility of Rays, is their Disposition to be turned more or less out of their Way in like Incidences on the same Medium. Mathematicians usually consider the Rays of Light to be Lines reaching from the luminous Body to 
the Body illuminated, and the refraction of those Rays to be the bending or breaking of those lines in their passing out of one Medium into another. And thus may Rays and Refractions be considered, if Light be propagated in an instant. But by an Argument taken from the Æquations of the times of the Eclipses of Jupiter's Satellites, it seems that Light is propagated in time, spending in its passage from the Sun to us about seven Minutes of time: And therefore I have chosen to define Rays and Refractions in such general terms as may agree to Light in both cases. (Newton, 1979 [1730]: 2) in bold above), of which 13 are material processes, and only one mental (argument).

La plupart de ceux qui ont écrit touchant les différentes parties de l'Optique se sont contentés de présupposer ces vérités. Mais quelques-uns plus curieux en ont voulu rechercher l'origine, et les causes, les considérant elles-mêmes comme des effets admirables de la Nature. En quoi ayant avancé des choses ingénieuses, mais non pas telles pourtant que les plus intelligents ne souhaitent des explications qui leur satisfassent davantage, je veux proposer ici ce que j'ai médité sur ce sujet, pour contribuer autant que je puis à l'éclaircissement de cette partie de la Science naturelle, qui non sans raison en est réputée une des plus difficiles. Je reconnais être beaucoup redevable à ceux qui ont commencé les premiers à dissiper l'obscurité étrange où ces choses étaient enveloppées, et à donner espérance qu'elles se pouvaient expliquer par des raisons intelligibles. (Huygens 1992(1690): 51-52)

In this 136-word extract from Huygens' book, there are 8 cases of nominalization, of which 3 are material (origine, cause, effets), and 5 are mental (explication, éclaircissement, raison $\mathrm{x} 2$, espérance).

\section{Ideology}

Thus we see that both of the features studied here - the use of personal pronouns subjects, and the nominalization of processes - betray the differing stances of these two authors. Newton's philosophy is empirical, in the spirit of Bacon and his own contemporary, Locke; his thought processes are inductive, starting with the data provided by experiment and building his theory on that basis. Huygens' philosophy is Cartesian, and consequently deductive; reason is primary and used to establish a theory which then may be tested against the available data. Of course it is true that these stances were not totally "pure"; Newton was probably aware of the sort of theory towards which he was moving, even while carrying out his experiments, and Huygens was presumably aware of the available evidence even while carrying out his reasoning. Nevertheless, the two stances remain diametrically opposed, and the difference of viewpoint is stark.

The fact that these differences of standpoint filter down to the way in which the language is encoded is particularly interesting in the context of a systemic functional approach to language. According to systemic functional theory, the level at which the language is encoded in speech or writing, the lexicogrammar, is determined by the semantic level, in terms of three semantic metafunctions, ideational, interpersonal and textual. This level in turn is determined by the level of context, labelled, genre or register, in terms of field, tenor and mode, and some commentators here distinguish two separate levels. This level itself is determined by ideology. This is sometimes presented in diagrammatic form as concentric circles (Martin 1992) or triangles (Eggins 1994). 
Fig.1. Representation of systemic functional approach to language

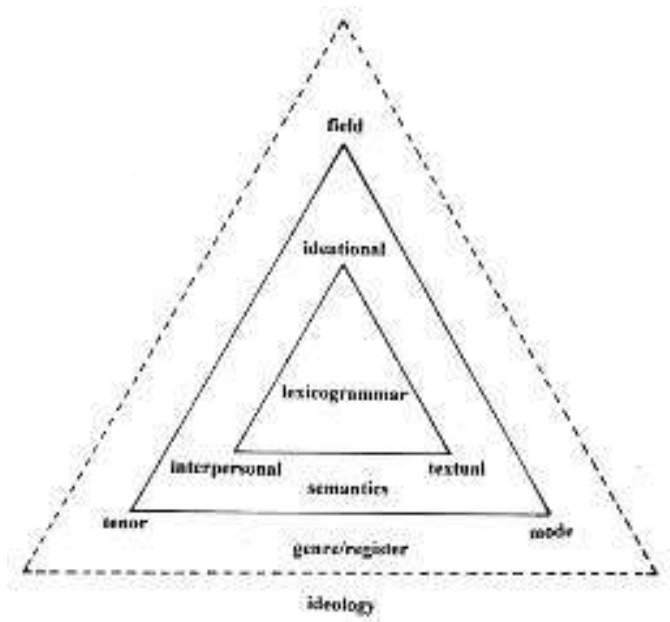

ADAPTED FROM EggINS (1994)

two texts by Newton and Huygens provide an interesting illustration of the way ideology, here in the form of empirical and Cartesian philosophies, filters down to the level of lexicogrammar, thus affecting the way in which the language is encoded. This is true even though at the level of genre they are virtually identical. They both have the same field, the physical properties of light; they have the same tenor, communication with their peers in the European scientific community of the time; and they have the same mode, a written document intended to be read silently and linearly. So it would appear that the affect of the ideological level on the lexicogrammar can be felt even though there is little effect at the level of genre, which is the same for both of these texts.

\section{And then...}

The next chapter in this story is that shortly afterwards French scientists abandoned the Cartesian approach, and adopted the empirical method. Thus natural philosophy was set on the road which was to lead to its being renamed as "science", and today it is difficult to conceive of scientific activity other than in inductive terms. Those who remained on the Cartesian side of the fence remained within the domain of philosophy. This is why today we think of Newton and his fellow experimenters as belonging to the history of science, but we consider that Descartes and his followers belong to the history of philosophy. Newton and Huygens' were working and writing at that crucial moment in history when what was to become science began to split off from philosophy. Thus we can genuinely talk about the beginnings of a new profession and the seeds of a new discipline.

\section{Conclusion}

Study of the relevant OED entries shows that the words professional, and profession were not available to Newton in the relevant sense to describe himself and his activity; he was however a professor. Nor was the word science available in the relevant sense, and the word scientist was not coined until much later. Newton would have called himself a philosopher, and his activity was a branch of philosophy. Study of extracts from Newton's Opticks and Huygens' Traité de la lumière shows that Newton uses the first person pronoun, I, much more frequently than Huygens' uses je, but that in addition, Huygens uses nous 
and on. Newton uses I with a significant number of material processes, whereas material process is rare with Huygens' personal pronoun subjects. On the other hand, with je and nous he uses a certain number of verbal processes, and with on, relational processes. Both Newton and Huygens use the nominalization of processes to a similar degree, but Newton nominalizes material process rather more than Huygens, and Huygens nominalizes mental process much more than Newton. These differences reflect Newton's empirical inductive stance, as opposed to the Cartesian deductive stance of Huygens. In terms of a systemic functional model, this means that the level of ideology is affecting the level of lexicogrammar. In this we can see the beginnings of the establishment of science as a discipline. And the word discipline brings us back to the OED which tells us that this word started life in the 14th century as "instruction imparted to disciples or scholars".

\section{BIBLIOGRAPHY}

\section{Corpus}

Huygens, Christiaan. 1992 [1690]. Traité de la lumière. Paris: Dunod.

Newton, Isaac. 1979 [1730]. Opticks, 4th edition. New York: Dover.

\section{References}

Atkinson, Dwight. 1999. Scientific Discourse in Sociohistorical Context, The Philosophical Transactions of the Royal Society of London, 1675-1975. Mahwah, New Jersey: Lawrence Erlbaum Associates.

Banks, David. 1999. "Aspects of the Development of Grammatical Metaphor in Scientific Writing”. Les Cahiers de l'APLIUT 19/1, 5-25.

Banks, David. 2001. "The reification of scientific process: The development of grammatical metaphor in scientific discourse". In Mayer, Felix (ed.), Language for Special Purposes: Perspectives for the New Millennium, Vol, 2. Tübingen: Gunter Narr, 555-563.

Banks, David. 2003. “The evolution of grammatical metaphor in scientific writing”. In SimonVandenbergen, Anne-Marie, Miriam Taverniers \& Louise Ravelli (eds.), Grammatical Metaphor, Views from systemic functional linguistics. Amsterdam: John Benjamins, 127-147.

Banks, David. Forthcoming. "Emerging scientific discourse in the late seventeenth century: A comparison of Newton's Opticks, and Huygen's Traité de la lumière”. Functions of Language 12:1.

Bazerman, Charles. 1988. Shaping Written Knowledge, The genre and activity of the experimental article in science. Wisconsin: University of Wisconsin Press.

Eggins, Suzanne. 1994. An Introduction to Systemic Functional Linguistics. London: Pinter.

Fara, Patricia. 2002. Newton the Making of Genius. London: Picador.

Gleik, James. 2003. Isaac Newton. London: Fourth Estate.

Gross, Alan G. 1996. The Rhetoric of Science. 2nd ed. Cambridge, Mass.: Harvard University Press.

Gross, Alan G., Joseph E. Harmon \& Michael Reidy. 2002. Communicating Science, The Scientific Article from the 17th Century to the Present. Oxford: Oxford University Press. 
Halliday, M.A.K. 1988. “On the Language of Physical Science”. In Ghadessy, Mohsen (ed.), Registers of Written English, Situational factors and linguistic features. London: Pinter, 162-178.

Halliday, M.A.K. 1994. An Introduction to Functional Grammar. 2nd ed. London: Arnold.

Halliday, M.A.K. 1998. "Things and relations, regrammaticising experience as technical knowledge”. In Martin, J.R. \& Robert Veel (eds.), Reading Science, Critical and functional Perspectives on Discourses of Science. London: Routledge, 185-235.

Halliday, M.A.K. \& J.R. Martin. 1993. Writing Science, Literacy and Discursive Power. London: Falmer Press.

Jones, Richard Foster. 1982 [1961]. Ancients and Moderns, A Study of the Rise of the Scientific Movement in Seventeenth-Century England. New York: Dover.

Martin, J.R. 1992. English Text, System and Structure. Amsterdam: John Benjamins.

Oxford English Dictionary. 1999. CD-ROM. Oxford University Press.

Vickers, Brian (ed.). 1997. English Science, Bacon to Newton. Cambridge: Cambridge University Press.

White, Michael. 1997. Isaac Newton, The Last Sorcerer. London: Fourth Estate.

\section{NOTES}

1. An earlier version of this paper was given at the 25th Colloque du GERAS, Poitiers, 2004.

2. Halliday (1988) is reprinted as a chapter of Halliday \& Martin (1993).

\section{ABSTRACTS}

This paper fits into the context of the beginnings of scientific English. Study of OED entries shows that Newton would have described himself as a "philosopher". The paper compares two features of Newton's Opticks, written 1675-1687, and Huygens' Traité de la lumière, published in 1690: personal pronoun subjects, and nominalized processes. Newton uses $I$ as subject, while Huygens uses je, nous, and on. Both Newton and Huygens use nominalized processes, to a similar extent, but Huygens nominalizes mental processes much more frequently than Newton does. These features are the lexicogrammatical realization of ideological differences. Shortly after this period francophone scientists were to adopt the empirical approach, laying the foundations of what would become the discipline of "science". Those who continued to follow the precepts of Cartesianism remained in the field of "philosophy".

Cet article a pour cadre le contexte des origines de l'anglais scientifique. Une étude des entrées de l'OED révèle que Newton se serait considéré comme un philosophe. L'article compare deux traits linguistiques présentés dans l'Opticks de Newton, écrit entre 1675 et 1687, et le Traité de la lumière de Huygens, publié en 1690 : les pronoms personnels sujets et les procès nominalisés. Newton utilise I comme sujet, tandis que Huygens emploie je, nous, et on. Ces deux auteurs utilisent les procès nominalisés à un degré similaire, mais Huygens nominalise les procès mentaux beaucoup plus fréquemment que Newton. Ces traits linguistiques sont la réalisation 
lexicogrammaticale de différences idéologiques. Peu de temps après cette période, les scientifiques francophones devaient adopter l'approche empirique, créant ainsi les bases de ce qui deviendrait la discipline de la "science ». Ceux qui continuèrent à suivre les principes cartésiens restaient dans le champ de la « philosophie».

INDEX

Mots-clés: Huygens (Christiaan), idéologie, linguistique diachronique, Newton, nominalisation, pronom personnel

Keywords: diachronic linguistics, Huygens (Christiaan), ideology, Newton, nominalization, personal pronoun

\section{AUTHOR}

\section{DAVID BANKS}

